\title{
ENERGETIC POTENTIAL AND ENVIRONMENTAL ASSESSMENT OF SOLID WASTES AS ALTERNATIVE FUEL FOR CEMENT PLANTS
}

\author{
HANNOUN, G. ${ }^{1}$ - JAOUAD, A. ${ }^{2}-$ SCHEBEK, L. ${ }^{3}-$ BELKZIZ, J. ${ }^{4}$ - OUAZZANI, N. ${ }^{1 *}$ \\ ${ }^{1}$ Laboratory of Hydrobiology, Ecotoxicology and Sanitation (LHEA, URAC 33), Department of \\ Biology, Faculty of Sciences Semlalia, Cadi Ayyad University, BP2390 Marrakesh, Morocco \\ (e-mail: hannoun.ghizlane05@gmail.com) \\ ${ }^{2}$ Laboratory of Innovation, Green Chemistry, Expertise and Sustainable Development \\ LICVEDDE, Department of Chemistry, Faculty of Sciences Semlalia, Cadi Ayyad University, \\ BP2390 Marrakesh, Morocco \\ (e-mail: jaouad@uca.ac.ma)
}

${ }^{3}$ FG Material Flow Management and Resource Management, Technical University of Darmstadt, Darmstadt, Germany

(e-mail: L.Schebek@iwar.tu-darmstadt.de)

${ }^{4}$ Ciment du Maroc Industry, Marrakesh, Morocco

(e-mail: j.belkziz@cimar.co.ma)

*Corresponding author

e-mail: ouazzani@uca.ac.ma; phone: +212-666-720-368

(Received 28 $8^{\text {th }}$ Jun 2019; accepted $16^{\text {th }}$ Oct 2019)

\begin{abstract}
The main objective of this paper is to evaluate the energetic potential and the environmental impacts of different kinds of wastes derived from different sources, namely olive Kernels (OK), sewage sludge (SS), chicken residues (CR), animal meal (AM) and fluffy RDF (F-RDF) and to figure out their feasibility as alternative fuels for cement plants. Decisive parameters promoting the use of wastes as secondary fuels such as: Calorific value, moisture, volatile matter, ash, chlorine, sulfur contents and trace elements were determined. A brief comparison of these fuels has been summarized. A model of fossil fuel savings is estimated using different scenarios with several substitution rates. The results show that chicken residues, fluffy RDF and olive kernels have the highest caloric values, which are $25.02 \mathrm{MJ} / \mathrm{kg}$, $24.79 \mathrm{MJ} / \mathrm{kg}$ and $21.68 \mathrm{MJ} / \mathrm{kg}$ respectively. Moreover, fluffy RDF can help mitigate carbon dioxide $\left(\mathrm{CO}_{2}\right)$ emissions due to its lower carbon content than coal, and its similar caloric power. In addition to their favorable calorific values, chicken residues and olive kernels allow for a significant reduction of fossil-derived $\mathrm{CO}_{2}$ due to their biogenic origin. Generally nitrogen oxide (NOx), sulfur dioxide $\left(\mathrm{SO}_{2}\right)$ emissions decrease while Co-firing waste with coal.
\end{abstract}

Keywords: co-processing, organic waste, calorific value, pollutants emissions, fossil fuel saving

\section{Introduction}

Developing countries face a huge challenge in the management and treatment of solid waste (Abdel-Shaf and Mansour, 2018): growing population and urbanization cause rising amounts of waste, landfill capacities are lacking. However, in the case of non-hazardous municipal solid waste, another option has shown its feasibility: Coprocessing of pretreated waste as an alternative fuel in cement production is widely applied in industrialized countries. It helps to reduce the volume of waste, conserve natural resources of primary energy, it contributes to reducing landfill emissions and has a positive effect on energy costs for the cement industry. 
Several studies analysed the feasibility of using waste in cement plants: Materials like waste oils (Kääntee et al., 2004), plastics (Feng et al., 1996), waste tires (Karell and Blumenthal, 2001; Hashem et al., 2019) and sewage sludge (Ninomiya et al., 2004) are often used as alternative fuels (AF) in the cement industry. Furthermore animal meal produced from the slaughterhouse residues can also be used as alternative fuel for cement co-combustion (Denafas et al., 2004; Bhatty, 2006). Apart from this, industrial waste such as non-recycled plastics and paper waste studied by Bourtsalas et al. (2018) and wood wastes investigated by Hossain et al. (2019), agricultural biomass and spent pot linings (Lechtenberg, 2009; Al-Salem et al., 2010; Ghenai et al., 2019) have been also used as alternative fuels in the cement industry for many years. Advances and challenges for the co-processing of waste were also studied by Stafford et al. (2015) in Latin American cement industry. The robustness of the co-processing as waste disposal technique was also revealed by the economic and environmental statistical analysis (Rahul et al., 2016).

Consequently, the use of non-hazardous solid waste could be an option to tackle waste management for developing countries, providing the double benefit of environmental protection and energy recovery. However, in developing countries there is generally a lack of data about the characteristics and quantities of non-hazardous municipal solid waste, the real calorific potential of wastes is little known. In addition no accurate data exists about the real environmental benefit that could be gained when using agricultural or biogenic wastes and their environmental impact as well. On real scale we can notice some modest experiences of co-processing of alternative fuels by local and international groups of cement companies which have been using tire chips and olive kernels as alternative fuels (GIZ, 2013) since a couple of years.

Cement is one of the most significant manufactured materials in the world. Global 2015 cement production is estimated at 4.6 billion tons (CEMBUREAU, 2015). Cement is the most important constituent of concrete, and every year, approximately $1 \mathrm{t}$ of concrete is expected to be produced for each human being in the world (Lippiatt and Ahmad, 2004) due to current developmental trends. Cement is a fine powder obtained from grinding clinker together with gypsum. Other additions like limestone, ashes, blast furnace slugs, and chemical additives may be added according to pertinent standards, (EN 197 2000). The most important ingredient of cement is clinker which is obtained by sintering a mixture of limestone, clay and iron ore at approximately $1450{ }^{\circ} \mathrm{C}$ by using flame temperatures of around $2000{ }^{\circ} \mathrm{C}$.

The main environmental impacts of cement production are associated with energy intensive processes (Madlool et al., 2011) and air emissions (Davidovits, 1994) where carbon dioxide $\left(\mathrm{CO}_{2}\right)$ is relevant because it accounts for approximately $6 \%$ of the total stationary source emissions worldwide (Metz, 2005). Emission in term of CO, $\mathrm{NO}_{\mathrm{X}}$ and $\mathrm{SO}_{2}$ generated from cement process contributes to greenhouse and acid rain effects (Zhang et al., 2011).

The cement industry is considered energy-intensive, because it needs to achieve high temperatures. Traditionally, it used fossil fuels such as coal, fuel oil, and petroleum coke. Their co-combustion in cement kilns is contributing to a rapid increase in the average temperature of the planet through the pollutants emitted to air (Harjanne and Korhonen, 2019).

In recent years utilization of alternative fuels in cement manufacturing has gained a wide attention due to its effectiveness in substituting the thermal energy requirement from fossil fuels and reducing the pollutant emission. Alkaline environment, high temperature and long residence time allow rotary kiln to burn a wide range of waste and 
hazardous material via co-processing (Rahman et al., 2015). In this process, waste is added to raw materials by replacing, in part, fuels or virgin raw material itself (Porto and Fernandes, 2006).

Studies on the impact of alternative fuels on environmental emission with regard to $\mathrm{CO}, \mathrm{NOx}, \mathrm{SO}_{2}$ and $\mathrm{CO}_{2}$ emissions have also been discussed (Rahman et al., 2015). The effect of various MBM parameters on the process of co-processing with coal, was determined through many experiments with different MBM/coal ratios carried by Gulyurtlu et al. (2005), these experiments demonstrate when the ratio of MBM is increased a minor impacts on emissions of $\mathrm{CO}$ and sulphur dioxide $\left(\mathrm{SO}_{2}\right)$ were noticed. Moreover, it was found while increasing MBM portion that NOx emissions decreases despite its high nitrogen content.

In addition to the studies that investigate the environmental impact of using waste in the cement industry, another research line focuses on the practical substitution rate for each type of alternative fuels.

This paper investigates chemical and physical characteristics of a diversity of alternative fuels, to evaluate their energetic potential and their environmental impact according to cement plants requirements. We highlight the potentials of a range of alternative fuels regarding the question of how much coal could be substituted and what impact on emissions one can expect. A calculation model of fossil fuels quantity that can be saved while using such waste is also estimated.

\section{Materials and methods}

\section{Samples description}

The present study was performed in Cadi Ayyad University, Marrakesh-Morocco in collaboration with Technical university of Darmstadt-Germany.

Different kinds of wastes were taken from different sources (Table 1). The target samples undergo a series of pretreatment including drying cutting and grinding to produce a fine powder in order to make their structure homogenous enough for the following analysis:

- Proximate analysis parameters: moisture, volatile, ash, and calorific value

- Ultimate analysis parameters: chlorine, sulphur as well as trace elements

The values obtained are results of three replicates. The results regarding moisture and calorific values could change over time, since the moisture affects the $\mathrm{CV}$ of the studied AF a continuous control of such parameters need to be performed before their use.

\section{Analytical method}

\section{Moisture content: according to DIN51718}

The working principle consists of drying samples at $105^{\circ} \mathrm{C}$ for $90 \mathrm{~min}$ in a Memmert oven. The sample $(1 \mathrm{~g})$ is spread evenly on a drying bowl crucible, weighed with $0,1 \mathrm{~g}$ accuracy and dried in an oven at $105 \pm 2{ }^{\circ} \mathrm{C}$ until mass constancy.

\section{Volatiles according to DIN 51720}

The working principle consists of treating the samples at $900{ }^{\circ} \mathrm{C}$ for 7 min using a Nabertherm oven. Approximately $1.0 \mathrm{~g}$ of the pre-dried and ground sample is weighed 
into a crucible which is placed in the oven preheated at $900 \pm 5^{\circ} \mathrm{C}$. After $7 \min ( \pm 5 \mathrm{~s})$, the crucible is removed and reweighed after cooling in a vacuum desiccator. The volatile matter content is calculated from the mass loss of the sample.

Table 1. Overview of solid waste tested and their origin

\begin{tabular}{|c|c|c|}
\hline Samples & Description & Sources \\
\hline $\begin{array}{l}\text { Olive mill wastewaters } \\
\text { “continuous system” (water- } \\
\text { solid mixture) (OMWC) }\end{array}$ & $\begin{array}{c}\text { Since olive production is done by } \\
\text { many processes (traditional and } \\
\text { continuous), different kinds of OK } \\
\text { were collected and other by-product } \\
(\mathrm{OMW}=\text { water + solid waste mixture) }\end{array}$ & $\begin{array}{l}\text { Olive Oil Factory, Marrakesh, } \\
\text { Morocco }\end{array}$ \\
\hline $\begin{array}{c}\text { Olive kernel "continuous } \\
\text { system" (OKC) }\end{array}$ & & $\begin{array}{l}\text { Olive Oil Factory, Marrakesh, } \\
\text { Morocco }\end{array}$ \\
\hline $\begin{array}{c}\text { Olive kernel "traditional } \\
\text { system" (OKT) }\end{array}$ & & $\begin{array}{l}\text { Olive Oil Factory, Marrakesh, } \\
\text { Morocco } \\
\end{array}$ \\
\hline $\begin{array}{l}\text { Olive kernel "canning industry" } \\
\text { (OKCa) }\end{array}$ & $\begin{array}{l}\text { OK generated from the process that } \\
\text { preserves olives in cans or jars for } \\
\text { future uses }\end{array}$ & $\begin{array}{l}\text { Canning Industry, Marrakesh, } \\
\text { Morocco }\end{array}$ \\
\hline Sewage sludge "M" & $\begin{array}{c}\text { The residual, semi-solid material that } \\
\text { is produced as a by-product during } \\
\text { sewage treatment of industrial or } \\
\text { municipal wastewater }\end{array}$ & $\begin{array}{l}\text { Wastewater Treatment Plant, } \\
\text { Marrakesh, Morocco }\end{array}$ \\
\hline Sewage sludge "G" & & $\begin{array}{c}\text { Wastewater Treatment Plant, } \\
\text { Ennigerloh, Germany } \\
\text { (Heidelberg Cement) }\end{array}$ \\
\hline Chicken waste & $\begin{array}{l}\text { Mixture of chicken heads, intestines, } \\
\text { feather and wings }\end{array}$ & $\begin{array}{c}\text { Dajajji Factory, Marrakesh, } \\
\text { Morocco }\end{array}$ \\
\hline Animal meal & $\begin{array}{l}\text { Waste derived from the slaughtering } \\
\text { of animals }\end{array}$ & $\begin{array}{l}\text { MVW Lechtenberg and Partner, } \\
\text { Duisburg, Germany }\end{array}$ \\
\hline Fluffy RDF & $\begin{array}{l}\text { Shredded plastic and small parts of } \\
\text { paper }\end{array}$ & $\begin{array}{l}\text { MVW Lechtenberg and Partner, } \\
\text { Duisburg, Germany }\end{array}$ \\
\hline
\end{tabular}

\section{Ash on the basis of DIN 51719}

The working principle consists of treating the samples at $815^{\circ} \mathrm{C}$ for $5 \mathrm{~h}$.

The ash content is determined by rising the temperature from $550{ }^{\circ} \mathrm{C}$ with $5 \mathrm{~K} / \mathrm{min}$ to $815^{\circ} \mathrm{C}$ and holding until constant weight (mass difference $\pm 0.05 \%$ ) is reached. The ash content is calculated from the mass loss of the sample.

\section{Chlorine and sulphur}

Sulphur and chlorine according to DIN51724-3/DIN 51727: The pre-dried and crushed sample is weighted in a porcelain crucible which contains a small quantity of $\mathrm{FePO}_{4}$ powder to help burning. With the aid of a catalyst layer of quartz powder and at high temperatures $\left(>1300{ }^{\circ} \mathrm{C}\right)$ the sulphur/chlorine is oxidized in an oxygen stream. In the resulting solutions, chlorine and sulphur are detected by means of volumetric analysis.

Sulfur titration: Metrohm titrator; standard solution $\mathrm{Ba}\left(\mathrm{ClO}_{4}\right)_{2},(0.005 \mathrm{~mol} / \mathrm{l})$

The entire solution from the combustion step is transferred into a $250 \mathrm{ml}$ volumetric flask. $50 \mathrm{ml}$ are pipeted off and added with same volume of acetone (for better 
precipitation of $\mathrm{BaSO}_{4}$ ). A few drops of indicator sulfonazo III are added. Under constant stirring barium perchlorate $\mathrm{Ba}\left(\mathrm{ClO}_{4}\right)_{2}$ solution is added until the color changes from violet to blue.

Chlorine titration: with $\mathrm{AgNO}_{3}(0.02 \mathrm{M})$

The remaining $200 \mathrm{ml}$ of the solution above is transferred into a $400 \mathrm{ml}$ beaker. $10 \mathrm{ml}$ of $\mathrm{HNO}_{3}$ are added, the titration is done by means of silver nitrate $\mathrm{AgNO}_{3}$.

\section{Calorific value according to DIN 51900}

For the determination of the calorific values a bomb calorimeter (IKA calorimeter $\mathrm{C}$ 7000 duo IKA C 5000) is used. Around 0.3 to $0.8 \mathrm{~g}$ of pre-dried and ground sample is weighed into a combustion capsule. The sample is mounted in the combustion bomb with an ignition. The bomb is placed into the calorimeter after been filled with 30 bar of oxygen.

The ignition and the measurement are done automatically. After the combustion the bomb must be checked for signs of incomplete combustion. Only gross calorific values (GCV) have been determined.

\section{Trace elements on the basis of DIN EN 13657:2003-01}

About $3 \mathrm{~g}$ of pre-dried and crushed sample is weighed into the reaction vessel. $21 \mathrm{ml}$ of $\mathrm{HCl}$ and $7 \mathrm{ml}$ of $\mathrm{HNO}_{3}$ are added. The digestion vessel is sealed and placed in the heating system. The samples can oxidize slowly with acids to ovoid explosion by the direct heating. It is recommended to increase the temperatures of the digestion mixture from $60{ }^{\circ} \mathrm{C}$ in modest steps each $20 \mathrm{~min}$ to an end temperature of $160{ }^{\circ} \mathrm{C}(60-80-120$ $160{ }^{\circ} \mathrm{C}$ ), the digestion lasts for $2 \mathrm{~h}$. After complete cooling, the reaction vessels are opened and the digestion solution is transferred into a $50 \mathrm{ml}$ plastic volumetric flask and filled with deionized water, then adjusted with $\mathrm{HNO}_{3}$.

The measurements were performed using Inductively Coupled Plasma ICP and Atomic Absorption Spectrometry. To determine mercury a cold vapor AAS (DIN EN 1483) was used.

\section{Elemental analysis $(C, N, O, P, F e)$}

The elemental analyses were done by means of, a scanning electron microscope (SEM) (TESCAN VEGA3 Centre d'Analyse et de Caractérisation CAC-Cadi ayyad University).

\section{$\mathrm{CO}_{2}$ and $\mathrm{SO}_{2}$ emission calculation}

$\mathrm{CO}_{2}$ and $\mathrm{SO}_{2}$ emissions prevision are calculated by the following formulas (Madlool et al., 2011; Lechtenberg and Diller, 2012):

$$
\begin{aligned}
& \mathrm{CO}_{\left[\mathrm{m}^{3} / \mathrm{kg} \mathrm{fuel}\right]}=\frac{1.854 * C_{[36]}}{100} \\
& \mathrm{SO}_{2_{\left[\mathrm{m}^{3} / \mathrm{kg} \mathrm{fuel}\right]}}=\frac{0.68 * S_{[06]}}{100}
\end{aligned}
$$

Note: $\left[\mathrm{m}^{3} \mathrm{~kg}-1\right.$ fuel] are referred to STP. 


\section{Net $\mathrm{CO}_{2}$ mitigation calculation}

The $\mathrm{CO}_{2}$ mitigation calculation is done through the following equations: first we calculate the equivalent amount of coal (W) that could substitute $1 \mathrm{t}$ of AF used based on their corresponding calorific values (CV) according to Equation 3, then we estimate its corresponding $\mathrm{CO}_{2}$ emitted amount $(\mathrm{X})$ based on Equation 4:

$$
\begin{aligned}
& W_{[t]} \text { of coal }=\frac{C V(A F)(\mathrm{kcal} / \mathrm{kg})}{C V(\mathrm{Coal})(\mathrm{kcal} / \mathrm{kg})} \\
& X_{[t]} \mathrm{CO}_{2_{\text {(coal })}}=W * 2.45_{[\mathrm{t}]} \mathrm{CO}_{2}
\end{aligned}
$$

The calculation of $\mathrm{CO}_{2}$ emissions from $1 \mathrm{t}$ of alternative fuels (Y) is done by using the carbon content $(\% \mathrm{C})$ determined by analysis (Table 5) and the molar mass $(\mathrm{M})$ of $\mathrm{CO}_{2}$ according to Equation 5.

$$
Y_{[t]} \mathrm{CO}_{2}(A F)=\frac{\left(C_{[96]} *(M(C)+2 M(O)) / M(C)\right)}{100}
$$

The amount of $\mathrm{CO}_{2}(\mathrm{Z})$ that could be saved by using $\mathrm{AF}$ instead of the equivalent amount of coal is calculated based on Equation 6:

$$
Z_{[t]} \mathrm{CO}_{2}=2.45_{[t]}-Y_{[t]}
$$

$\mathrm{W}, \mathrm{X}, \mathrm{Y}$ and $\mathrm{Z}$ are variables.

\section{Results and discussion}

\section{Energetic potential}

Proximate and ultimate analysis of the studied alternative fuels: The results regarding calorific value $(\mathrm{CV})$, moisture content, ash, volatiles, carbon, oxygen, nitrogen, sulphur and chlorine of different kinds of waste and of coal as fossil fuel reference are summarized in Table 2.

Substitution rate calculation: Table 3 shows the substitution factor of each alternative fuel referring to calorific value of $1 \mathrm{t}$ of coal or petcoke commonly used in cement facilities.

Olive residues sampled from different industrial units have lower heating values than coal between 18 and $21 \mathrm{MJ} \mathrm{kg}^{-1}$, with carbon content above $50 \%$. The moisture content ranges from 0.33 to $17 \%$, and ash content is between 2 and $30 \%$. The results show that olive kernels produced by means of traditional olive mills systems have the highest calorific value which is close to that of coal due to their higher oily as well as low ash contents compared to OK originated from continuous system (Table 2). Hence even that olive kernels are commonly used as alternative fuel it seems very interesting to compare OK from different sources and to highlight the impact of the source on their CV.

As mentioned in Table 3, olive residues have calorific values ranging between 4000 and $5000 \mathrm{kcal} \mathrm{kg}^{-1}\left(16.75-20.93 \mathrm{MJ} \mathrm{kg}^{-1}\right)$; therefore, $1.17 \mathrm{t}$ and $1.58 \mathrm{t}$ are needed to substitute $1 \mathrm{t}$ of coal or $1 \mathrm{t}$ of petcoke respectively, with olive kernels produced by means of traditional system. To maintain a good quality of the final product and 
convenient conditions of the combustion process while using agricultural biomass as alternative fuels, a substitution rate of $20 \%$ is recommended. In comparison to other wastes, the capital investment for their pretreatment is considered to be low (Demirbaş, 2003; Murray and Price, 2008). Some limitations of using biomass are their unavailability all around the year (Al-Hamamrea et al., 2017) and the high fluctuation of their heating value (Chinyama, 2011).

Table 2. Proximate and ultimate analysis of alternative fuels tested, and coal

\begin{tabular}{|c|c|c|c|c|c|c|c|c|c|c|}
\hline \multirow[b]{2}{*}{ Description } & \multicolumn{3}{|c|}{ Olive kernels (dm) } & \multirow{2}{*}{\begin{tabular}{|c} 
Dried olive-mill \\
wastewater \\
$(\mathbf{d m})$
\end{tabular}} & \multirow{2}{*}{\begin{tabular}{|c}
$\begin{array}{c}\text { Sewage } \\
\text { sludge "M" } \\
(\mathbf{d m})\end{array}$ \\
\end{tabular}} & \multirow{2}{*}{\begin{tabular}{|c|} 
Sewage \\
sludge \\
“G” $(\mathbf{d m})$
\end{tabular}} & \multirow{2}{*}{\begin{tabular}{|} 
Chicken \\
residues \\
$(\mathbf{d m})$
\end{tabular}} & \multirow{2}{*}{$\begin{array}{c}\text { Animal } \\
\text { meal } \\
(\text { ar })\end{array}$} & \multirow{2}{*}{\begin{tabular}{|c|} 
Fluffy \\
RDF \\
(ar)
\end{tabular}} & \multirow[b]{2}{*}{ Coal } \\
\hline & \begin{tabular}{|c|}
$\begin{array}{c}\text { Continuous } \\
\text { system }\end{array}$ \\
\end{tabular} & \begin{tabular}{|c|}
$\begin{array}{c}\text { Traditional } \\
\text { system }\end{array}$ \\
\end{tabular} & Canning & & & & & & & \\
\hline \multicolumn{11}{|c|}{ Proximate analysis } \\
\hline $\begin{array}{l}\text { Gross calorific } \\
\text { value }\left(\mathrm{MJ} \mathrm{kg}^{-1}\right)\end{array}$ & 18.67 & 21.68 & 21.23 & 18.08 & 17.718 & 14.938 & 24.794 & 17.584 & 25.016 & 25.5 \\
\hline Moisture (\%) & 2.79 & 2.28 & 1.79 & 2.06 & 2.46 & 1.37 & 1.05 & 5.75 & 1.14 & 3 \\
\hline $\operatorname{Ash}(\%)$ & 9.61 & 4.58 & 2.41 & 30.46 & 28.34 & 34.61 & 10.46 & 25.12 & 8.3 & 11.1 \\
\hline $\begin{array}{c}\text { Volatile matter } \\
(\%)\end{array}$ & 68.59 & 75.09 & 73.04 & 57.73 & 61.62 & 56.13 & 80.44 & 74.88 & 91.7 & 35.9 \\
\hline \multicolumn{11}{|c|}{ Ultimate analysis } \\
\hline Carbon $(\%)$ & 53.80 & 50.91 & 58.42 & 58.04 & 44.97 & 33.03 & 77.89 & 47 & 53 & 70.6 \\
\hline Oxygen $(\%)$ & 38.47 & 41.02 & 33.16 & $23.33 \%$ & 36.25 & 43.06 & 18.05 & n.a & n.a & n.a \\
\hline Nitrogen $(\%)$ & n.a & 6.17 & 3.63 & 2.75 & 8.29 & 10.06 & n.a & 10 & n.a & 1.2 \\
\hline $\begin{array}{c}\text { Phosphorus } \\
(\%)\end{array}$ & 0.15 & 0.04 & 0.05 & $0.04 \%$ & 1.14 & 3.45 & 0.80 & $3.4-5,9 *$ & n.a & n.a \\
\hline Iron $(\%)$ & n.a & n.a & n.a & 0.79 & 0.22 & 1.57 & n.a & n.a & n.a & n.a \\
\hline Sulfur (\%) & 0.14 & 0.08 & 0.06 & 0.13 & 1.05 & 1.30 & 0.52 & 0.7 & 0.2 & 1.3 \\
\hline Chlorine (\%) & 0.63 & 0.8 & 1.99 & 1.98 & 0.18 & 0.49 & 0.46 & 1.7 & 1.4 & 0.07 \\
\hline
\end{tabular}

*According to ICON IC Consultants (2001). n.a = not available, $\mathrm{dm}=$ dry matter, ar $=$ as received

Table 3. Fuel substitution calculation

\begin{tabular}{c|c|c|c|c}
\hline \multicolumn{3}{c|}{ Fuel substitution calculation } & \\
\hline & $\begin{array}{c}\text { Gross calorific } \\
\left.\text { value (kcal kg } \mathbf{~ k}^{-1}\right)\end{array}$ & $\begin{array}{c}\text { Substitution } \\
\text { factor CV coal } \\
\text { (ton) }\end{array}$ & $\begin{array}{c}\text { Substitution } \\
\text { factor CV } \\
\text { petcoke (ton) }\end{array}$ & $\begin{array}{c}\text { Saved fossil- } \\
\text { derived CO2 } \\
\text { (ton) }\end{array}$ \\
\hline Olive mill wastewaters & 4319 & 1.41 & 1.89 & 1.73 \\
Olive kernels continuous system & 4459 & 1.36 & 1.83 & 1.80 \\
Olive kernels traditional system & 5179 & 1.17 & 1.58 & 2.09 \\
Olive kernels canning & 5071 & 1.20 & 1.61 & 2.04 \\
Sewage sludge M & 4232 & 1.44 & 1.93 & 1.70 \\
Sewage sludge G & 3568 & 1.70 & 2.29 & 1.44 \\
Chicken residues & 5922 & 1.03 & 1.38 & 2.38 \\
Animal meal & 4200 & 1.45 & 1.95 & 1.69 \\
Fluffy RDF & 5975 & 1.02 & 1.37 & - \\
Coal & 6100 & 1 & - & - \\
Petcoke & 8200 & - & 1 & - \\
\hline
\end{tabular}

For sewage sludge the results show that the calorific value of sewage sludge " $\mathrm{M}$ " is $17.718 \mathrm{MJ} \mathrm{kg}^{-1}$, the moisture content is $2.46 \%$, and the ash content is $28.34 \%$, and 
carbon level of $44.97 \%$. For sewage sludge "G" the calorific value, moisture, ash, carbon, and sulphur are $14.938 \mathrm{MJ} / \mathrm{kg}, 1.37 \%, 34.61 \%, 33.03 \%$, and $1.30 \%$, respectively (Table 2). The ranges of different contents of elements and calorific values depend on the characteristics of the source and the treatment process of the sewage sludges. We can conclude that the sewage sludge " $M$ " has the highest caloric value along with carbon content of $44.97 \%$ and ash content higher than $11.1 \%$. Sewage sludge "M" and sewage sludge "G" have calorific values of 4232 and $3568 \mathrm{kcal} \mathrm{kg}^{-1}$ (17.71 $14.94 \mathrm{MJ} \mathrm{kg}^{-1}$ ), respectively. To replace $1 \mathrm{t}$ of coal/petcoke with sewage sludge "M", $1.44 \mathrm{t} / 1.93 \mathrm{t}$ are needed respectively (Table 3). To ovoid the possibility of an increased infeed of trace elements, Werther and Ogada (1999) suggested a maximum sewage sludge feeding rate of $5 \%$ of the clinker production capacity.

Compared to animal meal, chicken residues have the highest calorific value which is about $24.79 \mathrm{MJ} \mathrm{kg}^{-1}$ due to its oily texture and low moisture content of $1.05 \%$. Animal meal has a calorific value of $17.58 \mathrm{MJ} \mathrm{kg}^{-1}$ and moisture content of $5.75 \%$ (Table 2). Therefore $1.03 \mathrm{t}$ and $1.38 \mathrm{t}$ are needed to substitute $1 \mathrm{t}$ of coal or $1 \mathrm{t}$ of petcoke with chicken residues. Around $1.45 \mathrm{t}$ and $1.95 \mathrm{t}$ are needed to replace $1 \mathrm{t}$ of coal or $1 \mathrm{t}$ of petcoke with animal meal (Table 3). Animal meal is considered to be available compared to other alternative fuels and their feeding rate is variable from country to another, it is about 15\% of the energy needed in Spain cement kilns (Conesa et al., 2005), $40 \%$ for Australia (Rahman et al., 2015) and there is no limit in Switzerland.

Owing to its high calorific value of $25.01 \mathrm{MJ} \mathrm{kg}^{-1}$ which is similar to that of coal (Table 2), and with a low moisture of $1.14 \%$ and low ash content, fluffy RDF represents a very suitable alternative fuel for clinker burning. Fluffy RDF represents a perfect candidate for energetic recovery in these industries (Lechtenberg and Diller, 2012). In addition, only1.02 t to $1.37 \mathrm{t}$ of fluffy can substitute $1 \mathrm{t}$ of coal and $1 \mathrm{t}$ of petcoke, respectively. Among all tested alternative fuels, chicken residues and fluffy RDF as well as olive kernels produced by means of traditional olive mill system have the highest caloric power along with most favourable substitution factors for the replacement of $1 \mathrm{t}$ of coal/petcoke.

\section{Emissions}

\section{$\mathrm{CO}_{2}$ emissions}

$\mathrm{CO}_{2}$ emitted during co-processing such fuels in cement plant does not exceed the emission resulted from coal $\left[1.30 \mathrm{CO}_{2} \mathrm{~m}^{3} \mathrm{~kg}^{-1}\right.$ fuel] (Table 4). However the emitted quantity of $\mathrm{CO}_{2}$ in case of chicken residues co-firing is higher due to its high carbon level $\left[1.44 \mathrm{CO}_{2} \mathrm{~m}^{3} \mathrm{~kg}^{-1}\right.$ fuel].

The studied products account for pure biogenic material and therefore the coincineration of such materials contributes to global fossil-derived carbon dioxide mitigation. The extent of the mitigation can be appraised by the following simple calculation: Taking into account the IPCC default emission factor for coal $96 \mathrm{~kg}$ $\mathrm{CO}_{2} / \mathrm{GJ}$ (IPCC, 1996), $1 \mathrm{t}$ of coal emits approximately $2.45 \mathrm{t}$ of $\mathrm{CO}_{2}$. Hence, for each ton of coal substituted by $1.45 \mathrm{t}$ of $\mathrm{MBM}$ around $2.45 \mathrm{t}$ of fossil-derived carbon dioxide is saved. Or, vice versa, $1 \mathrm{t}$ of MBM can save around $1.69 \mathrm{t}$ of fossil-derived $\mathrm{CO}_{2}$ from coal (Table 3).

Plastics in general cannot be taken into account for fossil $\mathrm{CO}_{2}$ reduction calculation, this is owing to the fact that their origin is crude oil. Only bio-plastics made of renewable feedstocks (e.g. starch from cereals, corn, sugar cane) can be valuable for 
this. Mathematical modeling revealed a significant reduction of $\mathrm{CO}_{2}$ emissions, which is approximately $1.0 \mathrm{t}$ of $\mathrm{CO}_{2}$ per ton of coal replacement in case of the use of pure polyethylene and polystyrene plastics as alternative fuel (Murray and Price, 2008; Ariyaratne et al., 2011).

We can presume that $1 \mathrm{t}$ of chicken residues can save $2.38 \mathrm{t}$ of fossil-derived $\mathrm{CO}_{2}$ from coal, which allows a significant reduction in terms of fossil-derived $\mathrm{CO}_{2}$ emissions (Table 3). The saving of fossil-derived $\mathrm{CO}_{2}$ is not only a matter of biogenic carbon. If a fuel material has lower carbon than coal, but similar caloric power, as it is the case of fluffy RDF, then some net $\mathrm{CO}_{2}$ mitigation could be obtained.

Based on the Equations 3, 4, 5 and 6, 1 t of Fluffy RDF can substitute 0.96 t of coal, this quantity emits $2.4 \mathrm{t}$ of $\mathrm{CO}_{2}$ compared to $1.94 \mathrm{t} \mathrm{CO}_{2}$ emitted while using $1 \mathrm{t}$ of fluffy RDF which means $0.51 \mathrm{t} \mathrm{CO}_{2}$ could be saved by using $1 \mathrm{t}$ of fluffy RDF instead of the equivalent amount of coal.

\section{$\mathrm{SO}_{2}$, NOx emission}

As evident in Table 2 the sulphur content in olive residues is lower than the one in coal and therefore, co-firing biomass fuels with coal show a significant reduction of $\mathrm{SO}_{2}$ levels (Demirbaş, 2003; Sami et al., 2001) however, the nitrogen content is higher than 1.2\%. Experiments show, that using biomass implies low $\mathrm{SO}_{2}$ and $\mathrm{NOx}$ emissions due to lower sulphur and nitrogen contents compared to traditional fuels. Moreover, taking into account that the most of the nitrogen in biomass is converted to ammonia, which promotes the conversion of NOx to gaseous nitrogen, the emissions of NOx are also reduced (Demirbaş, 2003).

The sulfur content in sewage sludge varies between 1.05 and $1.3 \%$. It is similar to coal, which means that $\mathrm{SO}_{2}$ emissions will be the same in case of sewage sludge coprocessing together with coal. High nitrogen levels have been detected (Table 2). However, a study by the U.S. Environmental Agency (2008) showed that the use of sewage sludge reduces NOx emissions.

In animal meal the sulphur content is lower than that in coal (Table 2), therefore coprocessing such alternative fuels with coal has the capability of reducing $\mathrm{SO}_{2}$ levels. Chinyama (2011) showed that $\mathrm{SO}_{2}$ reduction depends mainly to the Ca content in MBM which has the capability to capture sulphur in solid phase. It was observed that $\mathrm{NO}_{\mathrm{X}}$ decreases with increasing MBM content in a coal-MBM blend, even if the nitrogen content in animal meal is 8 times higher than that in coal (Gulyurtlu et al., 2005; Ferreira et al., 2018). In contrast, a study launched by Denafas et al. (2004) mentioned that during incineration of MBM using heavy fuel oil, the emission of nitrogen oxides increases.

In fluffy RDF the sulphur content is about $0.2 \%$ (Table 2) which can decrease the level of $\mathrm{SO}_{2}$ emitted to air. The nitrogen content of the plastic, and the kiln operating conditions such as the flame temperature, air quantity, and oxygen level in the kiln are the main reasons for NOx emissions (Al-Salem et al., 2010).

Theoretically, all tested fuels can generate $\mathrm{SO}_{2}$, owing to their sulphur contents. The calculated specific $\mathrm{SO}_{2}$ quantities are displayed in Table 4. However, as explained by other studies, the specific conditions in clinker rotary kilns are very suitable to capture $\mathrm{SO}_{2}$ from fuels, which ultimately ends up in the clinker minerals (Torsten, 2005; Prakash et al., nd).

All samples present high content of nitrogen in comparison with coal, one would expect that NOx emissions would increase. However, the prediction of NOx emission from nitrogen content is not possible because its generation depends on the combustion 
temperature, although the fuel nitrogen contributes to some extent to the formation of NOx. NOx emissions from cement kilns mainly arise from oxidation of fuel-bound nitrogen and nitrogen in the combustion air. Clinker production is a high temperature process with flame temperatures up to some $2.000{ }^{\circ} \mathrm{C}$ in the sinter zone and material temperatures up to some $1.450{ }^{\circ} \mathrm{C}$. Due to the quality of the product the process must be operated with excess oxygen. Under these process conditions NOx is inevitably formed from the chemical reaction of the air components, i.e. nitrogen and oxygen. This NOx is called "thermal NOx" (BAT, 2010).

Table 4. $\mathrm{CO}_{2}$ and $\mathrm{SO}_{2}$ emissions calculation according to Equations 1 and 2

\begin{tabular}{c|c|c|c|c|c|c|c|c|c|c}
\hline Description & OKC & OKT & OKCa & OMWC & SS “M” & SS “G” & CR & AM & F-RDF & Coal \\
\hline Carbon (\%) & 53.80 & 50.91 & 58.42 & 58.04 & 44.97 & 33.03 & 77.89 & 47 & 53 & 70.6 \\
$\mathrm{CO}_{2}\left(\mathrm{~m}^{3} \mathrm{~kg}^{-1}\right.$ fuel) & 0.9975 & 0.9438 & 1.0831 & 1.0831 & 0.8337 & 0.6123 & 1.4440 & 0.8713 & 0.9826 & 1.3089 \\
Sulphur (\%) & $0.14 \%$ & $0.08 \%$ & $0.06 \%$ & $0.13 \%$ & $1.05 \%$ & $1.30 \%$ & $0.52 \%$ & $0.7 \%$ & $0.2 \%$ & $1.3 \%$ \\
$\mathrm{SO}_{2}\left(\mathrm{~m}^{3} \mathrm{~kg}^{-1}\right.$ fuel) & $0.95210^{3}$ & $0.54410^{-3}$ & $0.40810^{-3}$ & $0.88410^{-3}$ & $0.71410^{-2}$ & $0.88410^{-2}$ & $0.35410^{-2}$ & $0.47610^{-2}$ & $0.13610^{-2}$ & $0.88410^{-2}$ \\
\hline
\end{tabular}

\section{Chlorine}

Compared with coal, olive, animal residues, sewage sludge and fluffy RDF have higher chlorine levels (Table 2), thus increasing inner salt circulation of volatile elements inside the kiln. These give rise to increased coatings, build-ups and blockages in the colder parts of the preheater (Sami et al., 2001), hence reducing the efficiency of the plant.

A study revealed that biomass can contain considerable alkali and alkaline earth elements and chlorine, which, when mixed with other gas components derived from coal such as sulfur compounds, promotes a different array of vapor and fine particulate deposition in coal fired boilers (Lippiatt and Ahmad, 2004).

Chlorine may have an influence on clinker quality and therefore needs to be limited, as mentioned in the report from U.S. Environmental Protection Agency (2008), which refers to information from US-based Lehigh Cement. However, limitation of chlorine infeed to the kiln in general is advised (according to a rule of thumb, less than $300 \mathrm{~g}$ of total chlorine by raw materials and fuels per ton of clinker, which is valid for preheater kilns without bypass (Reference Guide, 2004). Chlorine-based salts are highly volatile under the kiln conditions, thus being the major driver for formation off coatings and cloggings in the preheater. Emission of $\mathrm{HCl}$, dioxins and furans can be increased by the presence of chlorine under specific conditions (Karstensen, 2008; BAT, 2010).

\section{Trace elements}

Table 5 shows a detailed characterization of different trace elements as well as a comparison between the hole results obtained regarding ultimate, proximate and chemical analysis with the guideline of requirement of cement plants (average, maximum).

With regard to trace elements like $\mathrm{Sb}, \mathrm{As}, \mathrm{Pb}, \mathrm{Cd}, \mathrm{Cu}, \mathrm{Ni} .$. the results revealed that for olive residues and chicken residues the majority of the elements metals are below the limits mentioned in the Guideline for the Energetic Recovery of Waste in Cement (GERWC) - Lime and Power plants in North Rhine Westphalia (GERWC, 2005; Table 5). 
Table 5. Physico-chemical analyses results and the guideline of requirement of alternative fuels in cement plants (average, maximum) and requirements from Heidelberg Cement Ennigerloh

\begin{tabular}{|c|c|c|c|c|c|c|c|c|c|c|c|c|}
\hline & \multirow[t]{2}{*}{ Unit } & \multicolumn{2}{|c|}{$\begin{array}{l}\text { Requirements of } \\
\text { cement plants for } \\
\text { the main burner } \\
\text { and requirements } \\
\text { from Heidelberg } \\
\text { cement Ennigerloh }\end{array}$} & \multirow[b]{2}{*}{$\begin{array}{c}\text { Olive } \\
\text { mill } \\
\text { waste } \\
\text { water } \\
\end{array}$} & \multirow[b]{2}{*}{$\begin{array}{c}\text { Olive } \\
\text { kernels } \\
\text { continuous }\end{array}$} & \multirow[b]{2}{*}{$\begin{array}{c}\text { Olive } \\
\text { kernels } \\
\text { traditional }\end{array}$} & \multirow[b]{2}{*}{$\begin{array}{c}\text { Olive } \\
\text { cannery }\end{array}$} & \multirow[b]{2}{*}{$\begin{array}{c}\text { Sewage } \\
\text { sludge } \\
M\end{array}$} & \multirow[b]{2}{*}{$\begin{array}{c}\text { Sewage } \\
\text { sludge } \\
\text { G }\end{array}$} & \multirow[b]{2}{*}{$\begin{array}{l}\text { Chicken } \\
\text { residues }\end{array}$} & \multirow[b]{2}{*}{ MBM } & \multirow[b]{2}{*}{$\begin{array}{c}\text { Fluffy } \\
\text { RDF }\end{array}$} \\
\hline & & From & To & & & & & & & & & \\
\hline $\begin{array}{c}\text { Water } \\
\text { content }\end{array}$ & M.-\% & & $<15$ & 2.06 & 2.79 & 2.28 & 1.79 & 2.46 & 1.37 & 1.05 & 5.75 & 1.14 \\
\hline Ash content & M.-\% & 10 & 20 & 30.46 & 9.61 & 4.58 & 2.41 & 28.34 & 34.61 & 10.46 & 25.12 & 8.3 \\
\hline $\begin{array}{c}\text { Calorific } \\
\text { value }\end{array}$ & $\mathrm{MJ} \mathrm{kg}^{-1}$ & $>20$ & & 18.07 & 18.66 & 21.68 & 21.22 & 17.71 & 14.93 & 24.78 & 17.58 & 25.01 \\
\hline $\begin{array}{c}\text { Volatile } \\
\text { constituents }\end{array}$ & M.-\% & n.a & n.a & 57.73 & 68.59 & 75.09 & 73.04 & 61.62 & 56.13 & 80.44 & 74.88 & 91.7 \\
\hline Chlorine & M.-\% & 0.6 & 1 & 1.98 & 0.63 & 0.81 & 1.99 & 0.18 & 0.49 & 0.46 & 0.7 & 0.8 \\
\hline Sulfur & M.-\% & & 2 & 0.13 & 0.14 & 0.08 & 0.06 & 1.05 & 1.30 & 0.52 & 1.7 & 0.2 \\
\hline \multirow{2}{*}{$\begin{array}{c}\text { Trace } \\
\text { elements }\end{array}$} & & & & & & & & & & & & \\
\hline & & Average & Max & & & & & & & & & \\
\hline Antimony & $\mathrm{mg} \mathrm{kg}^{-1}$ & 50 & 120 & 0.66 & 0.62 & 0.67 & 0.64 & 3.34 & 3.2 & 0.67 & 0.1 & 15.79 \\
\hline Arsenic & $\mathrm{mg} \mathrm{kg}^{-1}$ & 5 & 13 & 4.67 & 0.85 & 0.92 & 0.79 & 6.01 & 7.68 & 0.68 & 0.20 & 0.48 \\
\hline Beryllium & $\mathrm{mg} \mathrm{kg}^{-1}$ & 0.5 & $\mathrm{n} . \mathrm{a}$ & 0.30 & 0.17 & 0.17 & 0.16 & 0.26 & 0.22 & 0.17 & 5.19 & 0.17 \\
\hline Lead & $\mathrm{mg} \mathrm{kg}^{-1}$ & 70-190 & $200-500$ & 13.35 & 2.01 & 2.63 & 1.92 & 90.28 & 43.24 & 0.71 & 1.08 & 4.30 \\
\hline Cadmium & $\mathrm{mg} \mathrm{kg}^{-1}$ & 4 & 9 & 0.26 & 0.03 & 0.033 & 0.03 & 0.9 & 1.6 & 0.35 & 5 & 0.03 \\
\hline Chrome & $\mathrm{mg} \mathrm{kg}^{-1}$ & 40-125 & $120-250$ & 63.43 & 4.02 & 6.07 & 2.22 & 2751.43 & 193.82 & 1.03 & 11.18 & 5.16 \\
\hline Cobalt & $\mathrm{mg} \mathrm{kg}^{-1}$ & 6 & 12 & 4.67 & 0.30 & 0.34 & 0.31 & 4.67 & 17.29 & 0.33 & 1.68 & 0.34 \\
\hline Copper & $\mathrm{mg} \mathrm{kg}^{-1}$ & $120-350$ & $300-700$ & 33.38 & 8.01 & 10.12 & 4.2 & 128.71 & 341.23 & 71.87 & 16.18 & 10.39 \\
\hline Manganese & $\mathrm{mg} \mathrm{kg}^{-1}$ & $50-250$ & $100-500$ & 273.5 & 10 & 15.35 & 5.33 & 168.83 & 302.78 & 16.71 & 9.105 & 6.20 \\
\hline Nickel & $\mathrm{mg} \mathrm{kg}^{-1}$ & 50 & 100 & 36.72 & 2.05 & 3.13 & 1.07 & 17.55 & 41.65 & 1.20 & 1.25 & 0.69 \\
\hline Mercury & $\mathrm{mg} \mathrm{kg}^{-1}$ & 0.6 & 1.2 & 0.03 & 0.03 & 0.03 & 0.03 & 0.86 & 0.84 & 0.03 & 0.45 & 0.03 \\
\hline Selenium & $\mathrm{mg} \mathrm{kg}^{-1}$ & 3 & n.a & 0.78 & 0.65 & 0.67 & 0.64 & 3.29 & 3.2 & 2.19 & 0.323 & 0.69 \\
\hline Tellurium & $\mathrm{mg} \mathrm{kg}^{-1}$ & 3 & n.a & 1.75 & 1.67 & 1.68 & 1.62 & 1.91 & 4.80 & 1.67 & 7.17 & 1.73 \\
\hline Thallium & $\mathrm{mg} \mathrm{kg}^{-1}$ & 1 & 2 & 0.33 & 0.33 & 0.33 & 0.31 & 0.33 & 0.31 & 0.33 & 1.85 & 0.34 \\
\hline Vanadium & $\mathrm{mg} \mathrm{kg}^{-1}$ & 10 & 25 & 16.35 & 1.05 & 1.26 & 0.31 & 25.90 & 12.65 & 0.53 & 0.35 & 0.37 \\
\hline Zinc & $\mathrm{mg} \mathrm{kg}^{-1}$ & n.a & n.a & 43.39 & 9.54 & 13.74 & 8.25 & 578.35 & 2665.78 & 90.25 & 108.18 & 12.06 \\
\hline Tin & $\mathrm{mg} \mathrm{kg}^{-1}$ & 30 & 70 & 1.37 & 0.47 & 0.53 & 0.40 & 9.69 & 26.75 & 0.54 & 21.78 & 0.44 \\
\hline
\end{tabular}

MBM contains some 3.4-5.9\% P (Lechtenberg and Diller, 2012). Phosphorus is the most limiting factor for MBM firing, because it affects setting time and compressive strength development of cement as well.

The same considerations apply when dried sewage sludge is co-fired. As a rule, sewage sludge contains plenty of phosphorus, as it could be also shown by the examined sample "G" in particular, but also by sample " $M$ ".

$\mathrm{P}$ is absorbed by the clinker minerals to form C3P-C2S mixed crystals which decrease the $\mathrm{C} 3 \mathrm{~S}$ content, whilst increasing free lime. Altogether, the early strength of cement would be reduced when level of $\mathrm{P}_{2} \mathrm{O}_{5}$ in clinker is above $0.8 \%$ (Lechtenberg and Diller, 2012). 
Heavy metals are also present in sludge and are the major problem in terms of sludge management. However, positive results have been achieved in the case of SS additions in cement manufacturing.

As shown in Table 5 sewage sludge "M" contains higher levels of $\mathrm{Cr}$ and $\mathrm{V}$, while sewage sludge "G" contains high level of Co. The level of mercury (Hg) is high in both sewage sludge samples when compared to the other materials (Table 5) which comes from the cleaning process at the sewage plant and from the source of the wastewater (ICON IC Consultants Ltd, 2001). To use sewage sludge in cement industry, the suggested maximum mercury content is $0.5 \mathrm{mg} \mathrm{kg}^{-1}$ (Karstensen, 2008; Ninomiya et al., 2004). Conesa et al. (2005) affirmed that there was no correlation between sewage sludge feeding rate and heavy metal emissions. But Cartmell et al. (2006) reported earlier that sewage sludge causes an increase in heavy metal emissions compared to fossil fuels.

It were demonstrated that the content of some heavy metals such as $\mathrm{Cr}, \mathrm{Zn}$, and $\mathrm{Ni}$ have no influence on the formation of the clinker phases, the final compressive strength, and the initial setting time or hydration level when their concentrations are below $0.1 \%$ in the raw mixture. The concentrations of heavy metals in the clinker are related to their volatility during the burning process. More studies are needed to establish the reliability of these findings (Chen et al., 2010).

As it is the case of natural materials, also waste-derived fuels contain environmentally relevant elements. Our examinations show that the samples contain fairly low amounts of heavy metals and metalloids. When co-processed, most of the elements are captured by the clinker minerals. But mercury in particular, and also thallium are volatile elements, which are hardly bound in the clinker. Thus, such elements leave the kiln system via the stack. Sewage sludge may have the potential of containing increased amounts of mercury. This tendency has also been observed in our examinations, for sewage sludge $\mathrm{M}$ and $\mathrm{G}$ contain around $0.8 \mathrm{mg} \mathrm{kg}^{-1}$ of $\mathrm{Hg}$ (Table 5). Mercury emissions of clinker kilns can be mitigated by an array of specific measures, e.g. dust shuttling, the use of activated carbon as sorbent, or wet scrubbers (CSI, 2016).

When using alternative fuels, a thorough sampling and analysis regime should be implemented for monitoring environmentally relevant elements in those materials.

\section{Saving fuels estimation}

Based of the calculation models used by MVW Lechtenberg and partners which is one of the world's leading consulting firms for the implementation of alternative fuels from biomass and useable wastes in the cement industry, we were able to calculate the quantity of coal that can be saved using different substitution rate 5\%,10\% and $20 \%$ respectively of the studied alternative fuels with coal (Table 7).

The Kiln operation (hours and days), clinker production rate, specific heat consumption, heat consumption and the calorific value of each fuel (Fossil or AF) are the most important data that allow the calculation of the saved fossil fuel quantity (Table 6):

\section{Scenario 1: $100 \%$ coal}

The dosage of coal is obtained according to its corresponding calorific value and the heat consumption mentioned in Table 6. 


\section{Scenario 2: co-processing of coal and AF}

First we defined the substitution rate which is the ratio between heat portion and heat consumption, the heat portion of AF is calculated according to its calorific value and its dosed value which is the added quantity of AF that satisfy the choosing substitution rate. While the heat portion of the remaining coal is the subtraction between the heat consumption and the heat portion of $\mathrm{AF}$, the dosed quantity of the remaining coal in this scenario is the ratio between its CV and its heat portion. Savings of fossil fuels value is the ration of subtraction between the dosed remaining coal quantity in scenario 2 and the dosed quantity of coal in scenario 1 .

Table 6. Kiln data

\begin{tabular}{c|c|c}
\hline Kiln operation hours & {$\left[\mathrm{h} \mathrm{d}^{-1}\right]$} & 24 \\
Kiln operation days & {$\left[\mathrm{d} \mathrm{a}^{-1]}\right.$} & 330 \\
\hline & {$\left[\mathrm{t} \mathrm{d}^{-1}\right]$} & 65000 \\
Current clinker production rate & {$\left[\mathrm{t} \mathrm{h}^{-1}\right]$} & 2708 \\
& {$\left[\mathrm{t} \mathrm{a}^{-1}\right]$} & 21450000 \\
\hline Specific heat consumption & {$\left[\mathrm{kJ} \mathrm{kg}^{-1} \mathrm{clinker}\right]$} & 3500 \\
Heat consumption & {$\left[\mathrm{kJ} \mathrm{h}^{-1}\right]$} & 9479166667 \\
\hline
\end{tabular}

We can notice that the quantity of fossil fuels that can be saved is related directly to the substitution rate, calorific value and the dosing quantity of AF used for each scenario.

For a substitution rate of $5 \%$ and $10 \%$, we presume that SS with a calorific value of $17706 \mathrm{kj} \mathrm{kg}^{-1}$ and dosing quantity of $27 \mathrm{t} \mathrm{h}^{-1}$ and $53.8 \mathrm{t} \mathrm{h}^{-1}$ revealed the highest saving quantity of coal which is about $148352 \mathrm{t} \mathrm{a}^{-1}$ and $295606 \mathrm{t} \mathrm{a}^{-1}$ respectively (Table 7).

For the substitution rate of $20 \%$ versus $80 \%$ of coal, chicken residues revealed the highest saving fuels of $592038 \mathrm{t} \mathrm{a}^{-1}$.

Table 7. The saved quantity of coal using different substitution rate of 5\%, $10 \%$ and $20 \%$ respectively of the studied alternative fuels

\begin{tabular}{|c|c|c|c|c|c|c|}
\hline & \multirow{2}{*}{$\begin{array}{c}100 \% \text { Coal } \\
\text { Coal }\end{array}$} & \multicolumn{5}{|c|}{$95 \%$ Coal + 5\% AF } \\
\hline & & CR & $\mathbf{A M}$ & F-RDF & SS & OK \\
\hline Net caloric value $\left(\mathrm{kj} \mathrm{Kg}^{-1}\right)$ & 25522 & 24777 & 17572 & 25000 & 17706 & 21668 \\
\hline Substitution rate $(\%)$ & 0 & $95_{\text {coal }} / 5_{\mathrm{CR}}$ & $95_{\text {coal } /} 5_{\mathrm{AM}}$ & $95_{\text {coal }} / 59_{\text {F-Rdf }}$ & $95_{\text {coal }} / 5_{\mathrm{SS}}$ & $95_{\text {coal }} / 5_{\mathrm{OK}}$ \\
\hline Dosage fuels $\left(\mathrm{t} \mathrm{h}^{-1}\right)$ & 371.4 & $353_{\mathrm{coal} /} 19_{\mathrm{CR}}$ & $352.8_{\text {coal } /} / 27_{\mathrm{AM}}$ & $352.8_{\text {coal }} / 19_{\mathrm{F}-\mathrm{Rdf}}$ & $352.7_{\text {coal }} / 27_{\text {SS }}$ & $352.7_{\text {coal }} / 22_{\text {OK }}$ \\
\hline \multirow[t]{3}{*}{ Saving fuels $\left(\mathrm{t} \mathrm{a}^{-1}\right)$} & - & 146087 & 147230 & 147402 & 148352 & 147929 \\
\hline & $100 \%$ Coal & \multicolumn{5}{|c|}{$90 \%$ Coal $+10 \%$ AF } \\
\hline & Coal & CR & $\mathbf{A M}$ & F-RDF & SS & OK \\
\hline Net caloric value $\left(\mathrm{kj} \mathrm{Kg}^{-1}\right)$ & 25522 & 24777 & 17572 & 25000 & 17706 & 21668 \\
\hline Substitution rate $(\%)$ & 0 & $90_{\text {coal }} / 10_{\mathrm{CR}}$ & $90_{\text {coal }} / 10_{\mathrm{AM}}$ & $90_{\text {coal }} / 10_{\text {F-Rdf }}$ & $90_{\text {coal }} / 10_{\text {ss }}$ & $90_{\text {coal }} / 10_{\text {OK }}$ \\
\hline Dosage fuels $\left(\mathrm{t} \mathrm{h}^{-1}\right)$ & 371.4 & $334.1_{\text {coal }} / 38.4_{\mathrm{CR}}$ & $334.2_{\text {coal }} / 54_{\mathrm{AM}}$ & $334.2_{\text {coal }} / 38_{\text {F-Rdf }}$ & $334.1_{\text {coal }} / 53.8 \mathrm{ss}$ & $334.4_{\text {coal }} / 43.6_{\mathrm{OK}}$ \\
\hline \multirow[t]{3}{*}{ Saving fuels $\left(\mathrm{t} \mathrm{a}^{-1}\right)$} & - & 295250 & 294459 & 294804 & 295606 & 295185 \\
\hline & $100 \%$ Coal & \multicolumn{5}{|c|}{$80 \%$ Coal + $20 \%$ AF } \\
\hline & Coal & $\mathbf{C R}$ & $\mathbf{A M}$ & F-RDF & SS & OK \\
\hline Net caloric value $\left(\mathrm{kj} \mathrm{Kg}^{-1}\right)$ & 25522 & 24777 & 17572 & 25000 & 17706 & 21668 \\
\hline Substitution rate (\%) & 0 & $80_{\text {coal }} / 20_{\mathrm{CR}}$ & $80_{\text {coal }} / 20_{\text {AM }}$ & $80_{\text {coal }} / 20_{\text {F-Rdf }}$ & $80_{\text {coal }} / 20_{\text {ss }}$ & $80_{\text {coal }} / 20_{\mathrm{OK}}$ \\
\hline Dosage fuels $\left(\mathrm{t} \mathrm{h}^{-1}\right)$ & 371.4 & $297_{\text {coal }} / 76.7_{\mathrm{CR}}$ & $297.1_{\text {coal }} / 108_{\mathrm{AM}}$ & $297_{\text {coal }} / 76_{\text {F-Rdf }}$ & $297.2_{\text {coal }} / 107_{\mathrm{ss}}$ & 297 coal $/ 87.7$ OK \\
\hline Saving fuels $\left(\mathrm{t} \mathrm{a}^{-1}\right)$ & - & 589732 & 588919 & 589609 & 587915 & 589697 \\
\hline
\end{tabular}


The amount of fossil fuels that can be saved is directly influenced by the calorific value and the dosing quantity of the alternative fuel used. Higher substitution rate demands higher dosing quantity of alternative fuels and allow higher saving quantities of fossil fuels. The result connected with sewage sludge and olive kernels are based on the averages of the different sewage and olive kernel sources since the calorific value is not the same.

In this paper several alternative fuels that are being currently used in cement manufacturing, have been tested. These fuels have been critically analysed with regard to their gross calorific values, their levels of chlorine, sulphur, nitrogen and trace elements. Greenhouse gas emissions and environmental impact have been discussed as well.

In regards to calorific values fluffy RDF is the best option. It contributes to some net $\mathrm{CO}_{2}$ mitigation due to its lower carbon content than coal, while the calorific value is on a similar level. Nowadays the use of plastics as alternative fuel is standard in numerous cement plants. Depending on the feeding point, kiln or calciner burners, plastics have to be crushed into appropriate grain size, furthermore chlorine always comes along with mixed plastics. The depletion of chlorine in the treatment process of plastics is of utmost importance.

Chicken residues followed by olive kernels (traditional olive mill system, canning) also have high calorific value and it reduces the green house gas emission due to their biogenic origin. From the emission point of view agricultural biomass could be the best option but due to the unavailability of a particular agricultural biomass all around the year restrict their usage.

Despite the low calorific value of animal meal it can replace coal to some extent and it offers the advantage of fossil derived $\mathrm{CO}_{2}$ reduction. The environmental impacts are comparatively low. Still the processing costs are very high in the case of MBM.

Among the studied alternative fuel sewage sludge presents the lowest calorific value but the ash derived from the sludge can substitute raw material which is an additional advantage. In case of sewage sludge co-processing with coal a special attention need to be paid for trace elements, especially $\mathrm{Cr}, \mathrm{Co}, \mathrm{V}$ and $\mathrm{Hg}$.

The generation of nitrogen oxides is inherent to the high-temperature process of clinker production. It is normally not influenced by the use of alternative materials. Moreover, depending on the respective locations, the raw material situation can effect the emissions of sulfur dioxide, the content of heavy metal compounds in the exhaust gas is additionally determined by the input situation in the kiln (VDZ CONGRESS, 2002).

In spite of numerous researches to identify the potential benefits and barriers of using different alternative fuel, none of those studies indicate which fuel is better than the others. This is only because there are lots of criteria which need to be considered from different perspectives. Table 5 shows various criteria of the alternative fuels that have been discussed in this paper.

\section{Conclusion}

Based on the results obtained regarding the energetic potential and the environmental assessment: among all studied alternative fuels chicken residues, fluffy RDF and olive residues could be the best option as alternative fuels. The main advantages of using such fuels in cement industry are economic and environmental: 
These fuels could reduce the carbon footprint and the main atmospheric pollutants $\left(\mathrm{NOx}, \mathrm{SO}_{2} \ldots\right.$ ) that result from using fossil fuels and therefore the overall environmental impact of cement manufacturing operations. We presume also from our results that the replacement of coal with such fuels extends the supply of fossil fuels and is a safe way of absorbing waste which otherwise would present disposal problem especially in developing countries. In economic point of view and based on the estimated quantity of coal that can be saved we notice, the use of these waste as fuels saved huge amounts of fossil fuels which is considered to be economically viable.

Heavy metal emissions from the cement industry are a significant environmental concern and need to be controlled through appropriate measures, hence it is necessary that future studies consider the environmental impact from heavy metal emitted after adaptation and implementation of any alternative fuel, through an assessment of these metals released into the environment surrounding (air, soil water and plant from) the cement kilns co-burning waste. A life cycle assessment (LCA) methodology is recommended as well to quantify the potential environmental impacts of each scenario and to figure out the most environmentally friendly ones.

Acknowledgements. This work was supported by the German Academic Exchange Service "DAAD" and MVW Lechtenberg Projektentwicklungs- und Beteiligungsgesellschaft $\mathrm{mbH}$, in Duisburg, Germany: I would like to acknowledge, with grateful thanks, all individuals, companies and associations who have contributed in this work namely: Mrs Joanna Korneluk-Bruns, Dr Hansjoerg Diller, Mr Dirk Lechtenberg, and Heidelberg Cement Ennigerloh Germany.

\section{REFERENCES}

[1] Abdel-Shafy, H. I., Mansour, M. S. M. (2018): Solid waste issue: sources, composition, disposal, recycling, and valorization. - Egyptian Journal of Petroleum 27(4): 1275-1290.

[2] Al-Hamamrea, Z., Saidan, M., Rawajfeh, K., Alkhasawneh, H. E., Al-Shannag, M. (2017): Wastes and biomass materials as sustainable-renewable energy resources for Jordan. - Renewable and Sustainable Energy Reviews 67: 295-314.

[3] Al-Salem, S. M., Lettieri, P., Baeyens, J. (2010): The valorization of plastic solid waste (PSW) by primary to quaternary routes: from re-use to energy and chemicals. - Progress in Energy and Combustion Science 36(1): 103-29.

[4] Ariyaratne, W. K. H., Melaaen, M. C., Eine, K., Tokheim, L. A. (2011): Meat and bone meal as a renewable energy source in cement kilns: investigation of optimum feeding rate. - Renewable Energy and Power Quality Journal 2011(May): 1244-49.

[5] BAT Reference Document (2010): Best Available Techniques (BAT) Reference Document for the Production of Cement, Lime and Magnesium Oxide Industrial Emissions Directive 2010/75/EU. - Integrated Pollution Prevention and Control Joint Research Centre Institute for Prospective Technological Studies Sustainable Production and Consumption Unit European IPPC Bureau 2013.

[6] Bhatty, J. I. (2006): Effect of Minor Elements on clinker and Cement Performance: A Laboratory Analysis. - Portland Cement Association, Skokie, IL, pp. 31-34.

[7] Bourtsalas, A. C., Zhang, J., Castaldi, M. J., Themelis, N. J. (2018): Use of non-recycled plastics and paper as alternative fuel in cement production. - Journal of Cleaner Production 181: 8-16.

[8] Cartmell, E., Gostelow, P., Riddell-Black, D., Simms, N., Oakey, J., Morris, J., Jeffrey, P., Howsam, P., Pollard, S. J. (2006): Biosolids - a fuel or a waste? An integrated appraisal of five co-combustion scenarios with policy analysis. - Environ Sci Technol 40: 649-658. 
[9] CEMBUREAU (2015): The European Cement Association. - Activity Report, Brussels, Belgique.

[10] Chen, H., Ma, X., Dai, H. (2010): Reuse of water purification sludge as raw material in cement production. - Cement and Concrete Composites 32(6): 436-439.

[11] Chinyama, M. P. M. (2011): Alternative Fuels in Cement Manufacturing. - In: Manzanera, M. (ed.) Alternative Fuel. InTech, Rijeka.

[12] Conesa, J. A., Fullana, A., Font, R. (2005): Dioxin production during the thermal treatment of meat and bone meal residues. - Chemosphere 59(1): 85-90.

[13] CSI (2016): Guidance for Reducing and Controlling Emissions of Mercury Compounds in the Cement Industry. - Cement Sustainability Initiative (CSI), World Business Council for Sustainable Development, Geneva.

[14] Davidovits, J. (1994): Global warming impact on the cement and aggregates industries. World Resource Review 6: 263-278.

[15] Demirbas, A. (2003): Sustainable cofiring of biomass with coal. - Energy Conversion and Management 44(9): 1465-79.

[16] Denafas, G., Buinevicius, K., Urniezaite, I., Puškorius, R., Rekašius, J. (2004): Meat and bone meal incineration in terms of industrial and energetic infrastructure in Lithuania. Energetic and Environmental Aspects 4: 36-48.

[17] EN 197 2000: European Standard EN 197-1: Cement. Part 1: Composition, Specifications and Conformity Criteria for Common Cements.

[18] Feng, Z., Zhao, J., Rockwell, J., Bailey, D., Huffman, G. (1996): Direct liquefaction of waste plastics and coliquefaction of coal-plastic mixtures. - Fuel Processing Technology 49(1-3): 17-30.

[19] Ferreira, L. R. A., Otto, R. B., Silva, F. P., De Souza, S. N. M., Ando Junior, O. H. (2018): Review of the energy potential of the residual biomass for the distributed generation in Brazil. - Renewable and Sustainable Energy Reviews 94: 440-455.

[20] GERWC (2005): Guideline for the Energetic Recovery of Waste in Cement (GERWC) Lime and Power Plants in North Rhine Westphalia (Leitfaden zur Energetischen Verwertung von Abfällen in Zement-, Kalk- Und Kraftwerken in Nordrhein-Westfalen). 2. Ed. - Ministerium Für Umwelt Und Naturschutz, Landwirtschaft und Verbraucherschutz des Landes Nordrhein-Westfalen, Düsseldorf (in German).

[21] Ghenai, C., Inayat, A., Shanableh, A., Al-Sarairah, E., Janajreh, I. (2019): Combustion and emissions analysis of spent pot lining (SPL) as alternative fuel in cement industry. Science of the Total Environment 684: 519-526.

[22] GIZ (2013): Diagnostic de l'état de Gestion Des Déchets Non Dangereux et Évaluation Du Gisement Pouvant Être Valorisés En Tant Que Combustibles Secondaires de Substitution. - $\quad$ http://www.gd-maroc.info/fileadmin/user_files/pdf/Etudes/SMQAF_EvaluationduGisement-min.pdf.

[23] Gulyurtlu, I., Boavida, D., Abelha, P., Lopes, M. H., Cabrita, I. (2005): Co-combustion of coal and meat and bone meal. - Fuel 84: 2137-48.

[24] Harjannea, A., Korhonenc, J. M. (2019): Abandoning the concept of renewable energy. Energy Policy 127: 330-340.

[25] Hashem, F. S., Rasek, T. A., Mashout, H. A. (2019): Rubber and plastic wastes as alternative refused fuel in cement industry. - Construction and Building Materials 212: 275-282.

[26] Hossain, M. U., Poon, C. H., Wong, M. Y. K., Khine, A. (2019): Techno-environmental feasibility of wood waste derived fuel for cement production. - Journal of Cleaner Production 230: 663-671.

[27] ICON IC Consultants (2001): Pollutants in Urban Waste Water and Sewage Sludge Final Report. Chap. 2: Potentially Toxic Elements: Sources, Pathways, And Fate Through Urban Wastewater Treatment Systems. - ICON IC Consultants Ltd, London. 
[28] Kääntee, U., Zevenhoven, R., Backman, R., Hupa, M. (2004): Cement manufacturing using alternative fuels and the advantages of process modelling. - Fuel Processing Technology 85(4): 293-301.

[29] Karell, M. A., Blumenthal, M. H. (2001): Air regulatory impacts of the use of tire-derived fuel. - Environmental Progress 20(2): 80-86.

[30] Karstensen, K. H. (2008): Formation, release and control of dioxins in cement kilns. Chemosphere 70(4): 543-60.

[31] Lechtenberg, D. (2009): Spent cell linings from the aluminium smelting process as an alternative fuel and raw material for cement production. - Global Cement Magazine 2009(Jan): 36-37.

[32] Lechtenberg, D., Diller, H. (2012): Alternative Fuels and Raw Materials Handbook for the Cement and Lime Industry. Vols. 1 and 2. - Verlag Bau + Technik, Düsseldorf.

[33] Lippiatt, B., Ahmad, S. (2004): Measuring the life-cycle environmental and economic performance of concrete: the BEES approach. - International Workshop on Sustainable Development and Concrete Technology, Beijing.

[34] Madlool, N. A., Saidur, R., Hossain, M. S., Rahim, N. A. (2011): A critical review on energy use and savings in the cement industries. - Renewable and Sustainable Energy Reviews 15(4): 2042-60.

[35] Metz, B. (2005): Intergovernmental Panel on Climate Change IPCC Special Report on Carbon Dioxide Capture and Storage. - Cambridge University Press, for the Intergovernmental Panel on Climate Change, Cambridge.

[36] Murray, A., Price, L. (2008): Use of Alternative Fuels in Cement Manufacture: Analysis of Fuel Characteristics and Feasibility for Use in the Chinese Cement Sector. - National Laboratory, Berkeley.

[37] Ninomiya, Y., Zhang, L., Sakano, T., Kanaoka, C., Masui, M. (2004): Transformation of mineral and emission of particulate matters during co-combustion of coal with sewage sludge. - Fuel 83(6): 751-64.

[38] Porto, M. F. S., Fernandes, L. O. (2006): Understanding risks in socially vulnerable contexts: the case of waste burning in cement kilns in Brazil. - Safety Science 44(3): 24157.

[39] Prakash, S., Chandrasekhar, P., Rajasekar, L. (nd): UltraTech Cement Ltd. Using High Sulphur Raw Materials Fuels Cement Plant. - In: Cement Plant Environmental Handbook, Cemnet, India, pp. 140-142.

[40] Rahman, A., Rasul, M. G., Khan, M. M. K., Sharma, S. (2015): Recent development on the uses of alternative fuels in cement manufacturing process. - Fuel 145(April): 84-99.

[41] Rahul, B., Sadhan, K. G., Ulhas, V. P. (2016): Co-processing of industrial waste in cement kiln: a robust system for material and energy recovery. - Procedia Environmental Sciences 31: 309-317.

[42] Reference Guide (2004): Reference Guide for Process Performance Engineers. $1^{\text {st }}$ Ed. Holcim Group Support Ltd., Corportate Technical Services, Rapperswil-Jona.

[43] Sami, M., Annamalai, K., Wooldridge, M. (2001): Co-firing of coal and biomass fuel blends. - Progress in Energy and Combustion Science 27(2): 171-214.

[44] Stafford, F. N., Viquez, M. D., Labrincha, J., Hotza, D. (2015): Advances and challenges for the co-processing in Latin American cement industry. - Procedia Materials Science 9: 571-577.

[45] Torsten, S. (2005): Minderung Rohmaterialbedingter $\mathrm{SO}_{2}$ Emissionen in der Zementindustrie. - Verl. Bau und Technik, Düsseldorf.

[46] US Environmental Protection Agency (2008): Trends in Beneficial Use of Alternative Fuels and Raw Materials Cement Sector. - http://Www.Epa.Gov/Sectors/ Pdf/CementSector-Report.Pdf.

[47] VDZ (2002): Effects of the Use of Secondary Materials on Emissions in Clinker Production. - Dr.-Ing. Martin Oerter, Cement Industry Research Institute, Düsseldorf. 
[48] Werther, J., Ogada, T. (1999): Sewage sludge combustion. - Progress in Energy and Combustion Science 25(1): 55-116.

[49] Zhang, Y., Xue, S. C., Shao, S., Chen, Y., Liu, S.-L., Zhang, S.-S. (2011): Aspen Plusbased simulation of a cement calciner and optimization analysis of air pollutants emission. - Clean Technologies and Environmental Policy 13(3). 